\title{
Phenotypic Characterization of Immortalized Normal and Primary Tumor-Derived Human Prostate Epithelial Cell Cultures
}

\author{
Tracy S. Schwab, ${ }^{1}$ Tylitha Stewart, ${ }^{1}$ Jeff Lehr, ${ }^{2}$ Kenneth J. Pienta, ${ }^{2,3}$ \\ Johng S. Rhim, ${ }^{4}$ and Jill A. Macoska ${ }^{1,3 *}$ \\ 'Section of Urology, Department of Surgery, University of Michigan, Ann Arbor, Michigan \\ ${ }^{2}$ Section of Hematology/Oncology, Department of Internal Medicine, University of Michigan, \\ Ann Arbor, Michigan \\ ${ }^{3}$ Comprehensive Cancer Center, University of Michigan, Ann Arbor, Michigan \\ ${ }^{4}$ Center for Prostate Disease Research, Uniformed Services University of the Health \\ Sciences, Rockville, Maryland
}

BACKGROUND. Cell lines can provide powerful model systems for the study of human tumorigenesis. However, the human prostate cancer cell lines studied most intensively by investigators (PC3, DU145, and LNCaP) were established from metastatic lesions, and it is unlikely that they accurately recapitulate the genetic composition or biological behavior of primary prostate tumors. Cell lines more appropriate for the study of human prostate primary tumors would be those derived from spontaneously immortalized cells; unfortunately, explanted prostate cells survive only short-term in culture, and rarely immortalize spontaneously. Therefore, we examined whether cell lines developed through viral gene-mediated immortalization of human normal or primary tumor prostate epithelium express aspects of the normal or malignant phenotypes, and could serve as appropriate models for normal or transformed human prostatic epithelium.

METHODS. To accomplish these goals, we assessed the phenotypic expression of cell cultures established through the immortalization of normal (1532N, 1535N, 1542N, and PrEC-T) or malignant (1532T, 1535T, and 1542T) human prostate epithelium with the E6 and E7 genes of HPV-16, or the large T antigen gene of SV40.

RESULTS. Examination of these cell lines for their proliferative rates and their abilities to grow with or without serum or androgen stimulation, to form colonies in soft agar, or to form tumors in vivo, suggests that they may serve as valid, useful tools for the elucidation of prostate tumorigenesis. Moreover, the observation of structural alterations involving chromosome 8 , including gain of $8 \mathrm{q}$ in 3 of the 4 cell lines expressing aspects of the malignant phenotype, implies that these cell lines accurately recapitulate the genetic composition of primary prostate tumors.

Grant sponsor: National Institutes of Health; Grant numbers: R29 CA60948, 1P50 CA69568 SPORE in Prostate Cancer; Grant sponsor: American Cancer Society; Grant number: RPG-98-338-01-MGO.

${ }^{*}$ Correspondence to: Jill A. Macoska, Ph.D., Section of Urology, Department of Surgery, University of Michigan, 7306 CCGC, 1500 East Medical Center Drive, Ann Arbor, MI 48109-0946.

E-mail: jcoska@umich.edu

Received 1 November 1999; Accepted 16 March 2000 
CONCLUSIONS. Taken together, these data suggest that cell lines generated from immortalized normal or primary tumor epithelium may be useful for the elucidation of early transforming events in the prostate. Prostate 44:164-171, 2000. (c) 2000 Wiley-Liss, Inc.

KEY WORDS: tumorigenesis; transformation; cell lines; primary tumors; prostate

\section{INTRODUCTION}

Prostate cancer is a major health concern worldwide. There will be approximately 180,400 new cases of prostate cancer diagnosed in 2000, making it the most commonly diagnosed cancer in the United States [1]. Unfortunately, very little is known about the process of prostate cancer initiation and progression to the malignant phenotype. The uncertain time course and heterogeneity of the disease hinder elucidation of prostate tumorigenesis, and make the procurement of clinical specimens for study from appropriate time points during prostate tumor progression largely impossible.

Therefore, we and others have developed prostate cancer cell lines as model systems to examine the process of malignant transformation. In particular, the establishment of long-term cell cultures through the immortalization of normal and primary tumor-derived epithelium from radical prostatectomy specimens with the E6 and E7 genes of the human papilloma virus 16 (HPV-16), or the large $\mathrm{T}$ gene of the simian virus 40 (SV40), have provided valuable tools toward the analysis of tumor development in the prostate [2].

In this study, we report on the expression of the malignant phenotype in primary tumor-derived human prostate cell cultures. Our observations suggest that prostate epithelium immortalized through transfection with the HPV-16 E6 and E7 or SV40 large T genes may serve as valid, useful tools for the elucidation of malignant transformation in the prostate.

\section{MATERIALS AND METHODS Cell Culture}

The HT-29 human colon cell line was grown in minimum essential medium (MEM) (Gibco BRL, Gaithersburg, MD) supplemented with $10 \%$ fetal bovine serum (FBS) (BioWhittaker, Walkersville, MD) and 1\% penicillin/streptomycin/fungizone antibiotic mixture (BioWhittaker). All other cell lines were grown in defined keratinocyte-SFM (Gibco BRL), 5\% FBS, and 1\% penicillin/streptomycin/fungizone antibiotic mixture (BioWhittaker). All cell lines were grown at $37^{\circ} \mathrm{C}$ in a humidified incubator with $5 \% \mathrm{CO}_{2}$.

\section{Immortalization}

The $1532 \mathrm{~N}, 1535 \mathrm{~N}, 1542 \mathrm{~N}, 1532 \mathrm{~T}, 1535 \mathrm{~T}$, and $1542 \mathrm{~T}$ cell lines were produced through immortalization of primary human prostate epithelial cells obtained from radical prostatectomy by transduction with a recombinant retrovirus encoding the E6 and E7 genes of HPV-16, as previously described [2]. The PrEC-T cells were produced through immortalization of normal prostate epithelial cells (Clonetics, Inc., Walkersville, MD) by transfection with the pMT10D plasmid (Japanese Cancer Research Resources Bank, Tokyo, Japan) containing sequences encoding the simian virus 40 (SV40) large T antigen.

\section{Growth Curves}

Cells were detached using $0.05 \%$ trypsin and plated in triplicate at a density of 10,000 cells/well in sterile six-well tissue culture plates (Fisher Scientific, Hanover Park, IL). PrEC-T cells were plated at a density of 5,000 cells/well. Each cell line was grown in media either with or without serum supplemented with $0.1 \%$ bovine serum albumin (BSA) (Sigma Chemical Co., St. Louis, MO) for a period of 2 weeks, with media changes every $2-3$ days. Plates were incubated at $37^{\circ} \mathrm{C}$ in $5 \% \mathrm{CO}_{2}$. Twenty-four hours later (time point $0 \mathrm{hr}$ ), media were aspirated and wells were washed with 5 $\mathrm{ml}$ of sterile $1 \times$ phosphate-buffered saline (PBS). PBS was aspirated, and $2 \mathrm{ml}$ of hypotonic solution $(0.01 \mathrm{M}$ HEPES and $0.0015 \mathrm{M} \mathrm{MgCl}_{2}$ ) were added to each well. Plates were incubated for $10-15 \mathrm{~min}$ at room temperature on a rocking platform. Two hundred microliters of lysis buffer $(0.13 \mathrm{M}$ c-ethylhexadecyldimethylammonium bromide and 3\% acetic acid) were added to each well. Plates were incubated for $10 \mathrm{~min}$ at room temperature on a rocking platform. Ten milliliters of isoton II diluent solution (Coulter Corp., Miami, FL) were added to each well and gently mixed. Nuclei were counted using a Coulter Counter (Coulter Corp.). Averages and standard deviations of cell number were calculated for each time point.

\section{Colony Formation Assays}

Five hundred microliters of media and $500 \mu \mathrm{l}$ of $1 \%$ agar at $50^{\circ} \mathrm{C}$ were mixed in sterile $15-\mathrm{ml}$ conical tubes (Fisher Scientific) and quickly poured into each well of six-well sterile tissue culture plates. The plates were allowed to solidify for several hours. Cells were added to $500 \mu \mathrm{l}$ of warm media at densities of $10^{5}, 10^{4}$, or $10^{3}$, followed by the addition of $200 \mu l$ of sterile warm 
TABLE I. Genotypic and Phenotypic Characteristics of Immortalized Prostate Cell Lines

\begin{tabular}{|c|c|c|c|c|c|c|c|}
\hline $\begin{array}{l}\text { Cell } \\
\text { line }\end{array}$ & $\begin{array}{c}\text { Tissue } \\
\text { derivation }\end{array}$ & $\begin{array}{l}\text { Doubling } \\
\text { time }\end{array}$ & $\begin{array}{l}\text { Number of } \\
\text { colonies } \\
\text { (SD) }\end{array}$ & $\begin{array}{l}\text { Growth } \\
\text { in low } \\
\text { serum }\end{array}$ & $\begin{array}{l}\text { Androgen } \\
\text { sensitivity }\end{array}$ & $\begin{array}{l}\text { Tumor } \\
\text { formation } \\
\text { In vivo }\end{array}$ & $\begin{array}{l}\text { 8p status by } \\
\text { allelotyping/cytogenetics }{ }^{a}\end{array}$ \\
\hline $1532 \mathrm{~N}$ & Normal prostate & $32 \mathrm{hr}$ & None & Yes & No & ND & 2 copies of intact $8 \mathrm{p} / \mathrm{nd} /$ \\
\hline $1535 \mathrm{~N}$ & Normal prostate & $41 \mathrm{hr}$ & None & Yes & No & ND & 2 copies of intact $8 \mathrm{p} / \mathrm{nd} /$ \\
\hline $1542 \mathrm{~N}$ & Normal prostate & $48 \mathrm{hr}$ & None & Yes & No & ND & 2 copies of intact $8 \mathrm{p} / \mathrm{nd} /$ \\
\hline PREC-T & Normal prostate & $36 \mathrm{hr}$ & $76(6)$ & Yes & ND & ND & nd/gain of $8 \mathrm{q}$ \\
\hline $1532 \mathrm{~T}$ & Malignant prostate & $24 \mathrm{hr}$ & $308(17)$ & Yes & No & No & One copy of $8 p$ deleted/[iso(8q)] \\
\hline $1535 \mathrm{~T}$ & Malignant prostate & $27 \mathrm{hr}$ & $168(11)$ & Yes & No & No & $\begin{array}{l}2 \text { copies of intact } 8 p / \text { nonclonal } \\
\text { deletion of one copy of } 8 p\end{array}$ \\
\hline $1542 \mathrm{~T}$ & Malignant prostate & $31 \mathrm{hr}$ & $132(17)$ & Yes & No & No & $\begin{array}{l}\text { One copy of } 8 \mathrm{p} \text { deleted/ } \\
\text { structural alterations of } \\
\text { chromosome } 8\end{array}$ \\
\hline HT-29c & Malignant colon & $25 \mathrm{hr}$ & $2,240(339)$ & ND & ND & Yes $^{\mathrm{b}}$ & 1 copy of $8 p$ deleted/[iso(8q)]) \\
\hline
\end{tabular}

${ }^{a}$ As reported here and in Bright et al. [2] and Macoska et al. [7].

${ }^{\mathrm{b}}$ As reported in Gustafson et al. [31].

'Included as a control; not derived from prostate tissue.

$\mathrm{ND}=$ not determined

water and $300 \mu \mathrm{l}$ sterile $1 \%$ agar $\left(50^{\circ} \mathrm{C}\right)$. Tubes were quickly mixed and poured onto the solidified layer of the six-well plates and allowed to solidify for several hours. Each plate was fed with $1 \mathrm{ml}$ of the appropriate media and placed at $37^{\circ} \mathrm{C}$ in a humidified incubator containing $5 \% \mathrm{CO}_{2}$. Each well was fed with $1 \mathrm{ml}$ of media every 3 days. After 3 weeks, cells were stained by overnight incubation with $10 \mu \mathrm{g} / \mathrm{ml}$ tetrazolium violet (Sigma Chemical Co.) in the media at $37^{\circ} \mathrm{C}$ with $\mathrm{CO}_{2}$. Each well was viewed and colonies were counted. HT-29 cells were used as positive controls for colony formation.

\section{Tumor Formation in Athymic Mice}

To determine tumorigenicity in vivo for the 1532T, 1535T, and $1542 \mathrm{~T}$ cell lines, $1 \times 10^{7}$ cells in $0.2 \mathrm{ml}$ of phosphate-buffered saline (PBS) were injected subcutaneously into the mid-dorsal interscapular region of adult athymic mice. The mice were observed for 5 months for tumor development.

\section{Androgen Sensitivity Assays}

Ten thousand cells of the $1535 \mathrm{~N}, 1535 \mathrm{~T}, 1532 \mathrm{~T}$, or $1542 \mathrm{~T}$ lines were plated into sterile six-well plates. Media containing no serum was supplemented with $0.1 \%$ BSA with no R1881 (methyltrienolone) (New England Nuclear Life Sciences, Boston, MA) as controls or concentrations of $10^{-7}, 10^{-8}$, or $10^{-9}$ MR1881. Plates were placed into $37^{\circ} \mathrm{C}$ humidified incubators with $5 \% \mathrm{CO}_{2}$ for 1 week with changes of media every 2 days. Cells were lysed and nuclei were counted as described above.

\section{Immunohistochemistry}

Cells were detached using trypsin and plated into sterile chamber slides (Fisher Scientific). Media were aspirated and the wells were washed with $1 \times$ PBS. Cells were fixed using a $50 \%$ methanol $/ 50 \%$ acetic acid solution for $15 \mathrm{~min}$ at $4^{\circ} \mathrm{C}$. Wells were washed with $1 \times$ PBS, and cells were stained using a pan cytokeratin antibody mixture containing clones C-11, PRK-26, CY-90, KS-1A3, M20, and A53-B/A2 or an isotype control antibody (Sigma Chemical Co.), using the UniTect ${ }^{\mathrm{TM}}$ immunohistochemistry detection system (Oncogene Science, Inc., Cambridge, MA), following the manufacturer's protocol. Slides were viewed using light microscopy.

\section{RESULTS}

Expression of the malignant phenotype was assessed for all cell lines by evaluating their proliferative rates (doubling times), their ability to grow in low serum and form colonies in soft agar and in vivo in athymic mice, and their sensitivity to androgen.

\section{Growth Curves}

Differences in cell doubling times for cells grown in the presence or absence of fetal bovine serum (FBS) were examined. The 1532T, 1535T, and the $1542 \mathrm{~T}$ human malignant prostate cell lines had faster doubling times than the $1532 \mathrm{~N}, 1535 \mathrm{~N}$, and $1542 \mathrm{~N}$ human normal prostate cell lines. Specifically, the doubling times for the malignant cell lines were in the range of 24-31 $\mathrm{hr}$, whereas the range of the normal cell lines was from 
1535 Cells

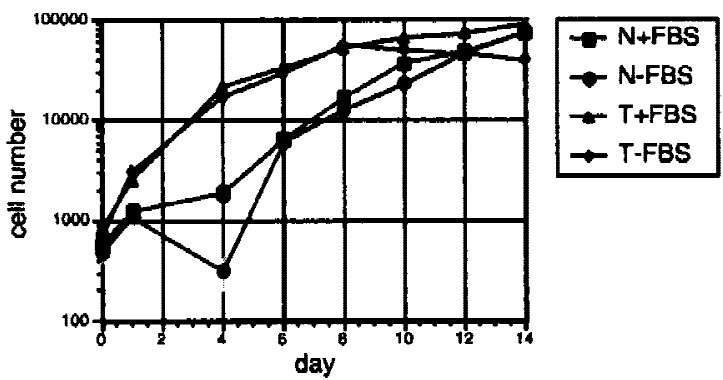

1542 Cells

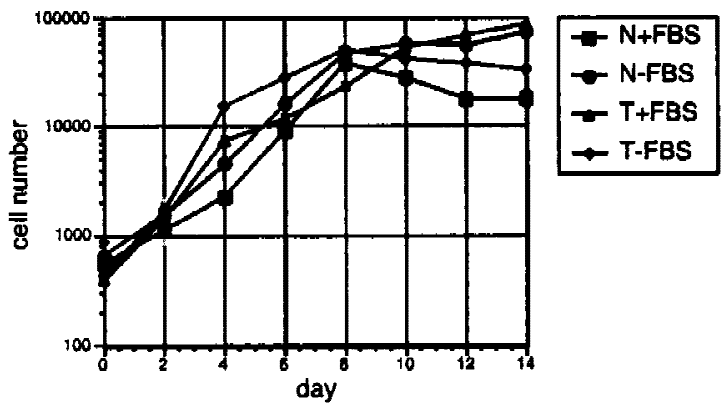

1532 Cells

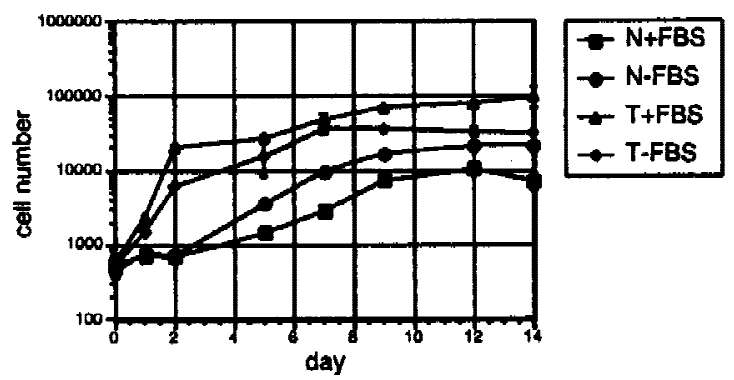

PrEC-T Cells

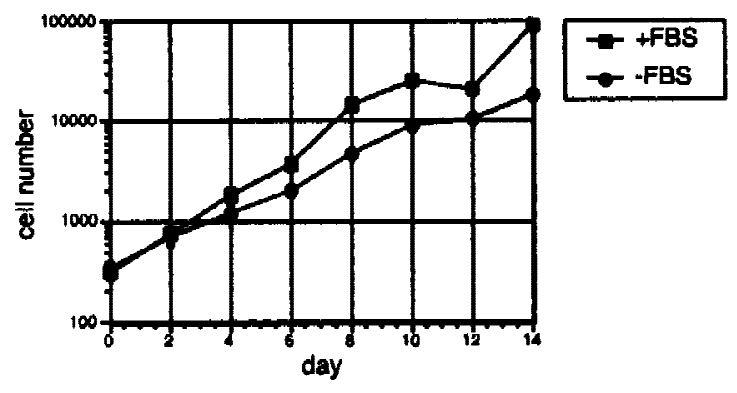

Fig. I. Effect of fetal bovine serum (FBS) on cell growth. Cell number (y-axis, logarithmic scale) at consecutive time points over a 2-week period ( $\mathrm{x}$-axis, linear scale) is shown for normal-derived cells grown in the presence (solid squares) or absence (solid circles) of FBS, and for tumor-derived cells grown in the presence (solid triangles) or absence (solid diamonds) of FBS. Upper left, I535 cells; upper right, 1532 cells; lower left, 1542 cells; lower right, PrEC-T cells.

32-48 hr (Table I). The PrEC-T cell line, which was established from normal prostatic epithelium after stable transfection with the SV40 large T antigen gene, had a doubling time of $36 \mathrm{hr}$, which was intermediate to those of the normal and tumor-derived prostate cell lines. No significant differences in growth rates were observed for any of the cell lines when grown in the presence or absence of FBS (Fig. 1). Hence, the tumor lines, as well as the normal lines, were able to grow in low serum.

\section{Colony Formation}

The ability of cells to form colonies in soft agar denotes that they have lost contact inhibition, a trait of the malignant or transformed phenotype. In order to determine whether cells demonstrated this trait, they were embedded in $0.5 \%$ agar and allowed to grow for 3 weeks, using HT-29 cells as a positive control for colony formation. The only cell lines that were able to form colonies in this assay were the HT-29, 1532T, 1535T, 1542T, and PrEC-T cell lines. The ability of prostate cell lines to form colonies in soft agar was $1532 \mathrm{~T}>1535 \mathrm{~T}>1542 \mathrm{~T}>$ PrEC-T. The 1532N, 1535N, and $1542 \mathrm{~N}$ cell lines were unable to produce any colonies in this assay (Table I).

\section{Tumor Formation in Athymic Mice}

Subcutaneous inoculation of $1 \times 10^{7}$ cultured cells into athymic mice failed to produce measurable tumors from the 1532T, 1535T, or $1542 \mathrm{~T}$ cell lines after 5 months of observation.

\section{Androgen Sensitivity Assays}

In order to see if the cell lines were sensitive to androgen, the $1535 \mathrm{~N}, 1532 \mathrm{~T}, 1535 \mathrm{~T}$, and $1542 \mathrm{~T}$ cells were grown in serum-free media at $0,10^{-7}, 10^{-8}$, and $10^{-7} \mathrm{M}$ R1881. Less than a twofold difference in growth was observed for cells exposed to androgen compared to the controls in any of the cell lines tested (Fig. 2).

\section{Immunohistochemistry}

In order to see if the cell lines were entirely epithelial in origin and without fibroblastic or neuroendo- 


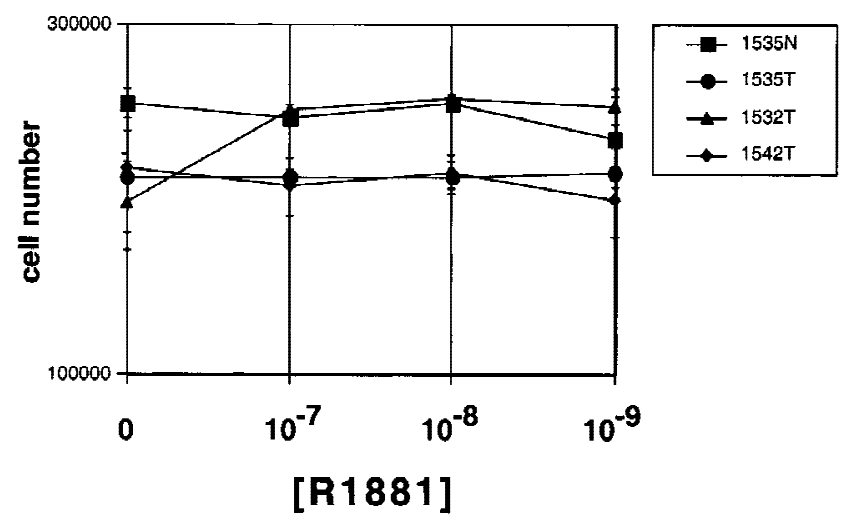

Fig. 2. Androgen sensitivity assay. Sensitivity to androgen was assessed for $1535 \mathrm{~N}, 1532 \mathrm{~T}, 1535 \mathrm{~T}$, and $1542 \mathrm{~T}$ cells after growth in serum-free media at $0,10^{-7}, 10^{-7}$, and $10^{-7} \mathrm{M}$ RI88I. Less than a twofold difference in growth was observed for cells exposed to a synthetic androgen, methyltrienolone (RI88I), compared to the controls in any of the cell lines tested.

crine contamination, cells were stained using a cytokeratin antibody mixture containing anti-cytokeratin antibodies and compared to cells stained with an isotype control (Table I). All of the cells examined stained uniformly and completely for cytokeratins, demonstrating that the cell lines were entirely epithelial and without fibroblast contamination (Fig. 3).

\section{DISCUSSION}

Cell lines can provide powerful model systems for studying the acquisition and expression of the malignant phenotype for the tissues from which they were derived. This is especially true when correlations between gross genotypic changes and expression of the malignant phenotype are attempted, as such studies using mouse models are often confounded by problems associated with mouse-human synteny. Even so, the human prostate cancer cell lines studied most intensively by prostate cancer investigators (PC3, DU145, LNCaP, and TSU-Pr1) were all established from metastatic lesions [3-6]. As such, it is unlikely that these cell lines accurately recapitulate the genetic composition or biological behavior of primary prostate tumors. Cell lines more appropriate for the study of human prostate primary tumors would be those derived from spontaneously immortalized cells; unfortunately, explanted prostate cells survive only short-term in culture, and rarely immortalize spontaneously. The use of viral transforming proteins to immortalize normal and primary tumor-derived human prostatic epithelium has allowed the continual propagation of these cells in vitro [2]. The cell lines examined in the present study were created through the
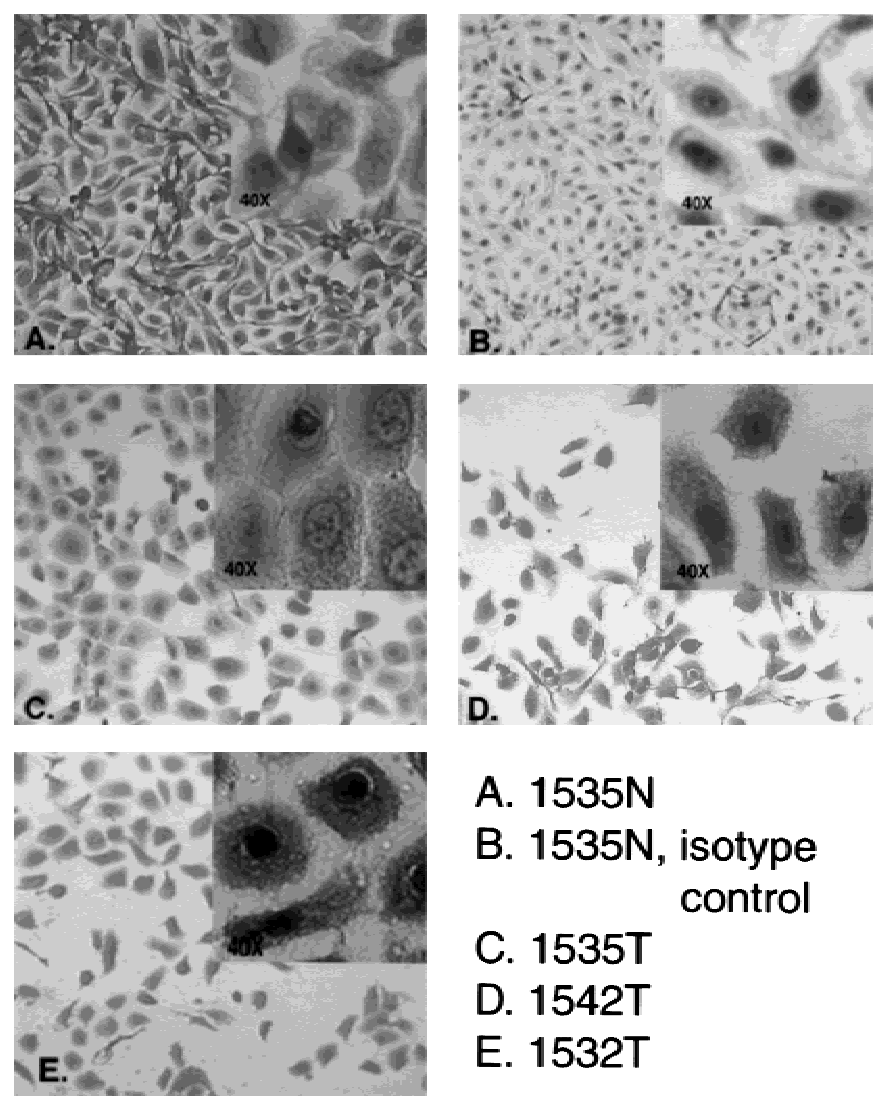

Fig. 3. Cytokeratin expression. Cells were stained using a panel of anti-cytokeratin antibodies. Photomicrographs of the stained slides taken at $10 x$ and $40 \times$ (insets) magnification are shown for cells stained with anti-cytokeratins in (A) I535N cells, (C) I535T cells, (D) I542T cells, and (E) I532T cells, or (B) the isotype control in $1535 \mathrm{~N}$ cells.

transduction, and subsequent immortalization, of normal and malignant prostatic tissues with the E6 and E7 transforming genes of HPV-16 or with the large T antigen gene of SV40 [2,7].

The experiments reported here were designed to assess the extent to which cell lines developed through immortalization of normal or primary tumor-derived prostatic epithelium with viral genes would express aspects of the normal or malignant phenotypes. This information would indicate whether such cell lines successfully recapitulated the biological behavior of the normal or malignant prostatic epithelium from which they were derived, and hence, whether they could serve as useful model systems for prostate biology and malignant transformation.

We first examined the growth of HPV-16 E6/E7 immortalized cell lines in the presence or absence of growth factors. All prostate cell lines examined $(1532 \mathrm{~N}, 1535 \mathrm{~N}, 1542 \mathrm{~N}, 1532 \mathrm{~T}, 1535 \mathrm{~T}$, and $1542 \mathrm{~T})$ were able to grow in the absence of serum, with or without androgen supplementation, at rates comparable to 
those achieved with serum added to the media. We then examined the doubling times of the HPV-16 E6/ E7 immortalized cells under normal growing conditions (with serum). Interestingly, doubling times for the malignant cell lines were $24-31 \mathrm{hr}$, considerably shorter than those of the normal cell lines at 32-48 hr. Thus, the first observed phenotypic difference between HPV-16 E6/E7 immortalized cells was shorter doubling times for primary tumor- compared to normal-derived prostatic epithelial cell lines. The second phenotypic difference observed for the HPV-16 E6/E7 immortalized cells was that all three primary tumorderived cell lines, but none of the corresponding normal-derived cell lines, were able to form colonies in soft agar. Thus, the primary tumor-derived cell lines were clearly distinguishable from the normal-derived cell lines by both a rapid doubling rate and the demonstration of anchorage independence. Not surprisingly, an inverse relationship was observed between doubling time and ability to form colonies in soft agar. Of the primary tumor-derived cell lines, the one with the shortest doubling time, $1532 \mathrm{~T}$, was also the one with the greatest ability to form colonies in soft agar (308 \pm 17$)$. In contrast, the primary tumor-derived cell line with the longest doubling time, $1542 \mathrm{~T}$, was least able to form colonies in soft agar $(168 \pm 11)$. Thus, if doubling time and anchorage independence can be used as criteria to measure expression of the malignant phenotype, then these cell lines may be ranked by their abilities to do so as 1532T > 1535T > 1542T.

The PrEC-T cell lines demonstrated a phenotype with aspects common to both the HPV-16 E6/E7 immortalized normal- and primary tumor-derived cells. Like the HPV-16 E6/E7-immortalized cells, PrEC-T cells were able to grow in low serum and did not respond to androgen stimulation. However, the doubling time for PrEC-T cells was $36 \mathrm{hr}$, which was intermediate to those of the normal- and primary tumorderived prostate cell lines. Also, PrEC-T cells were the only normal-derived cells to demonstrate any ability to form colonies in soft agar, though this ability was limited $(76 \pm 6)$. Thus, it appears that transfection with large $\mathrm{T}$ antigen resulted in both the immortalization and early transformation of PrEC-T cells.

These observations are consistent with other studies suggesting that the mechanism by which expression of the HPV-16 E6 and E7 genes results in cellular immortalization is through inactivation of the p53 protein by viral E6, destabilization of the $\mathrm{Rb}$ protein by viral E7, and activation of telomerase [8-11]. The combined effect of these activities is to bypass cell cycle checkpoints, reestablish telomere lengthening, and overcome replicative senescence, i.e., become immortalized. None of these events, however, are sufficient for cellular transformation or expression of the malig- nant phenotype [12]. In contrast, the SV40 large T antigen, which also abrogates the $\mathrm{p} 53$ and $\mathrm{Rb}$ pathways, can mediate both cellular immortalization and transformation [13-15]. Cells transformed by SV40 typically express some aspects of the malignant phenotype, including reduced dependency on growth factor (e.g., serum) requirements and anchorage independence [16]. It has been proposed that the ability of SV40 large $\mathrm{T}$ antigen to induce transformation may be due to mutations in other cellular genes not directly effected by $\mathrm{T}$ antigen [17]. Therefore, the ability of the SV40 large T-transfected, but not HPV-16 E6/E7transfected, normal prostate cells to express aspects of the malignant phenotype consistent with initial transformation may be due to differences in the genetic background of these cells. These differences are likely due to genetic alterations acquired due to, or consequent to, expression of viral proteins and the immortalization process. For example, many cytogenetic changes have been described for cells immortalized through transfection with HPV or SV40 [11,18-21].

None of the HPV-16 immortalized human prostate primary tumor-derived cell lines examined here were able to form detectable tumors in vivo in athymic mice. These findings are similar to those reported for CA-HP-10 cells, an HPV-18 immortalized human prostate adenocarcinoma-derived cell line, which were able to form only small nodules of nonproliferating cells in athymic mice [22]. Bright et al. also reported that subcutaneous injection of HPV-16 E6/E7 immortalized primary tumor-derived prostate cancer cell lines 1510-CPTx, 1512-CPTx, or 1519-CPTx failed to produce tumors in vivo in athymic mice [2]. Taken together, these studies suggest that cell lines developed from human prostate primary tumors are unable to express the full spectrum of the malignant phenotype. Rather, these cells express phenotypic traits perhaps more consonant with the primary, localized tumors from which they were derived (faster proliferation rate, reduced dependence on growth factors, and anchorage independence) and are unable to express phenotypic traits associated with more aggressive, metastatic tumors (e.g., the ability to form tumors in vivo). It is perhaps not surprising that human prostate cell lines capable of forming tumors in vivo were all derived from metastatic lesions and possess very aberrant genotypes [3-6,23]. It is possible, then, that genetic alterations in addition to those demonstrated by the cell lines examined here (see below) may be required for full expression of the malignant phenotype.

Of the genetic changes observed in the cell lines utilized in this study, it is interesting to note that 4 of the 5 cells lines expressing aspects of the malignant phenotype (1532T, 1542T, PreC-T, and HT-29) demon- 
strated structural alterations of chromosome $8[2,7,18]$. The 1532T and HT-29 cell lines are characterized by $\mathrm{i}(8 \mathrm{q})$ chromosome formation; the $1542 \mathrm{~T}$ karyotype includes i(8q), der(8;20)(q10;p10), and der(8;21)(p10;q10) chromosomes; and PrEC-T demonstrates gain of the $8 \mathrm{q}$ chromosomal region [7]. Therefore, gain of all or part of $8 \mathrm{q}$ was observed in three prostate-derived cell lines (1532T, 1542T, and PrEC-T), and was accompanied by the loss of $8 p$ sequences in 2 of the 3 cell lines (1532T and 1542T). Deletion of one or both copies of $8 p$ is a very frequent and likely early event in prostate tumorigenesis [24-26]. Moreover, other studies have reported $8 \mathrm{q}$ gain in advanced prostatic cancer [27-30]. Therefore, it is certainly possible that loss of $8 \mathrm{p}$ sequences and/or gain of $8 \mathrm{q}$ sequences contributed to the ability of these cells (especially PrEC-T) to express aspects of the malignant phenotype. If so, these cell lines, and others like them, generated from normal or primary tumor epithelium, may offer unique models for prostate tumorigenesis, and may help elucidate early transforming events in the prostate.

\section{ACKNOWLEDGMENTS}

The authors thank Dr. Suzanne Topalian for her kind gift of the HPV-immortalized cell lines.

\section{REFERENCES}

1. Greenlee RT, Murray T, Bolden S, Wingo PA. Cancer statistics 2000. CA Cancer J Clin 2000;50:7-33.

2. Bright $K$, Vocke CD, Emmert-Buck MR, Duray PH, Solomon D, Fetsch P, Rhim JS, Linehan WM, Topalian SL. Generation and genetic characterization of immortal human prostate epithelial cell lines derived from primary cancer specimens. Cancer Res 1997;57:995-1002.

3. Kaign ME, Narayan KS, Ohnuki Y, Lechner JF, Jones LW. Establishment and characterization of a human prostatic carcinoma cell line (PC-3). J Urol 1979;17:16-23.

4. Stone KR, Mickey DD, Wunderli H, Mickey GH, Paulson DF. Isolation of a human prostate carcinoma cell line (DU145). Int J Cancer 1978;21:274-281.

5. Horoszewicz AS, Leong SS, Kawinski E, Karr JP, Rosenthal H, Chu TM, Mirand EA, Murphy GP. LNCaP model of human prostatic carcinoma. Cancer Res 1983;43:1809-1818.

6. Hzumi T, Yazaki T, Kanoh S, Kondo I, Koiso K. Establishment of a new prostatic carcinoma cell line (TSU-PR1). J Urol 1987; 137:1304-1306.

7. Macoska JA, Beheshti B, Rhim JS, Hukku B, Lehr J, Pienta KJ, Squire JA. Genetic characterization of immortalized prostate epithelial cell cultures: evidence for structural rearrangements of chromosome 8 and $\mathrm{i}(8 \mathrm{q})$ chromosome formation in primary tumor-derived cells. Cancer Genet Cytogenet 2000; in press.

8. Huibregtse JM, Beaudenon SL. Mechanism of HPV E6 proteins in cellular transformation. Semin Cancer Biol 1996;7:317-326.

9. Jones DL, Thompson DA, Munger K. Destabilization of the RB tumor suppressor protein and stabilization of p53 contribute to HPV type 16 E7-induced apoptosis. Virology 1997;239:97-107.

10. Steeenbergen RDM, Walboomers JMM, Meijer CJLM, van der
Raaij-Helmer EMH, Parker JN, Chow LT, Broker TR, Snijders PJF. Transition of human papillomavirus type 16 and 18 transfected human foreskin keratinocytes towards immortality: activation of telomerase and allele losses at 3p, 10p, 11q and/or 18q. Oncogene 1996;13:1249-1257.

11. Coursen JD, Bennett WP, Gollahon L, Shay JW, Harris CC. Genomic instability and telomerase activity in human bronchial epithelial cells during immortalization by human papillomavirus-16 E6 and E7 genes. Exp Cell Res 1997;235:245-253.

12. Morales CP, Holt SE, Ouellette M, Kaur KJ, Yan Y, Wilson KS, White MA, Wright WE, Shay JW. Absence of cancer-associated changes in human fibroblasts immortalized with telomerase. Nat Genet 1999;21:115-118.

13. Brugge JS, Butel JS. Role of the simian virus 40 gene A function in maintenance of transformation. J Virol 1975;15:619-635.

14. Martin RG, Chou JY. Simian virus 40 functions required for the establishment and maintenance of malignant transformation. J Virol 1975;15:599-612.

15. Tegtmeyer P. Function of simian virus 40 gene A in transforming infection. J Virol 1975;15:613-618.

16. Jha KK, Banga S, Palejwala V, Ozer HL. SV40-mediated immortalization. Exp Cell Res 1998;245:1-7.

17. Ozer HL, Banga SS, Dasbupta T, Houghton JM, Hubbard K, Jha KK, Kim S-H, Lehahan M, Pang Z, Pardinas JR, Patsalis P. SV40mediated immortalization of human fibroblasts. Exp Gerontol 1996;31:303-310.

18. Gilles C, Piette J, Rombouts S, Laurent C, Foidart J-M. Immortalization of human cervical keratinocytes by human papillomavirus type 33. Int J Cancer 1993;53:872-879.

19. Oda D, Bigler L, Mao E-J, Disteche CM. Chromosomal abnormalities in HPV-16 immortalized oral epithelial cells. Carcinogenesis 1996;17:2003-2008.

20. Hoffschir F, Ricoul M, Dutrillaux B. SV40-transformed human fibroblasts exhibit a characteristic chromosomal pattern. Cytogenet Cell Genet 1988;49:264-268.

21. Ray FA, Peabody DS, Cooper J, Scott-Cram L, Kraemer PM. SV40 T antigen alone drives karyotype instability that precedes neoplastic transformation of human diploid fibroblasts. J Cell Biochem 1990;42:13-31.

22. Weijerman PC, Konig JJ, Wong ST, Niesters HG, Peehl DM. Lipofection mediated immortalization of human prostatic epithelial cells of normal and malignant origin using human papillomavirus type 18 DNA. Cancer Res 1994;54:5579-5583.

23. Beheshti B, Karaskova J, Park OC, Squire J, Beatty BG. Identification of a high frequency of chromosomal rearrangements in the centromeric regions of prostate cancer cell lines by sequential Giemsa-banding and spectral karyotyping. Mol Diagn 2000; 5:23-32.

24. Macoska JA, Trybus TM, Benson PD, Sakr WA, Grignon DJ, Wojno KD, Pietruk T, Powell IJ. Evidence for three tumor supressor gene loci on chromosome $8 \mathrm{p}$ in human prostate cancer. Cancer Res 1995;55:5390-5395.

25. Vocke C, Pozzatti RO, Bostwick DG, Florence CD, Jennings SB, Strup SE, Duray PH, Liotta LA, Emmert-Buck MR, Linehan WM. Analysis of 99 microdissected prostate carcinomas reveals a high frequency of allelic loss on chromosome 8p12-21. Cancer Res 1996;56:2411-2416.

26. Prasad MA, Wojno KJ, Macoska JA. Homozygous and frequent deletion of proximal $8 p$ sequences in human prostate cancers: identification of a potential tumor suppressor gene site. Genes Chromosomes Cancer 1998;23:255-262.

27. Macoska J, Trybus TM, Sakr WA, Wolf MC, Benson PD, Powell 
IJ, Pontes JE. Fluorescence in situ hybridization (FISH) analysis of $8 \mathrm{p}$ allelic loss and chromosome 8 instability in human prostate cancer. Cancer Res 1994;54:3824-3830.

28. Van Den Berg C, Guan X-Y, Von Hoff D, Jenkins R, Bittner M, Griffin C, Kallioniemi O, Visakorpi T, McGill J, Herath J, Epstein J, Sarosdy M, Meltzer P, Trent J. DNA sequence amplification in human prostate cancer identified by chromosome microdissection: potential prognostic implications. Clin Cancer Res 1995;1: 11-18.

29. Takahashi S, Alcaraz A, Brown JA, Borell TJ, Herath JF, Bergstralh EJ, Lieber MM, Jenkins RB. Aneusomies of chromosomes 8 and $\mathrm{Y}$ detected by fluorescence in situ hybridization are prog- nostic markers for pathological stage $\mathrm{C}\left(\mathrm{pT}_{3} \mathrm{~N}_{0} \mathrm{M}_{0}\right)$ prostate carcinoma. Clin Cancer Res 1996;2:137-145.

30. Jenkins RB, Qian J, Lieber MM, Bostwick DG. Detection of cmyc oncogene amplification and chromosomal aneusomies in metastatic prostatic carcinoma by fluorescence in situ hybridization. Cancer Res 1997;57:524-531.

31. Gustafson CE, Wilson PJ, Lukeis R, Baker E, Woollatt E, Annab L, Hawke L, Barrett JC, Chenevix-Trench G. Functional evidence for a colorectal cancer tumor supperssor gene at chromosome 8p22-23 by monochrome transfer. Cancer Res 1996;56: $5238-5245$. 